\title{
Two Pathogenic Variants in Two Ultra Rare Syndromes; Smith- Kingsmore Syndrome and Rubinstein Taybi Syndrome Type2
}

\author{
Yesim Ozdemir $^{* 1}$, Murat Cag ${ }^{2}$, Munis Dundar ${ }^{3}$, Aslihan Kiraz ${ }^{4}$, Cihan Meral ${ }^{5}$ \\ ${ }^{1}$ Uskudar University, Medical Faculty, Medical Genetics Department, Umraniye, 34768 Istanbul, Turkey \\ ${ }^{2}$ Memorial Bahcelievler Hospital, General Surgery Department, 34188, Istanbul \\ ${ }^{3}$ Erciyes University Medical Faculty, Medical Genetics Department, Kayseri, Turkey \\ ${ }^{4}$ Kayseri State Hospital, Medical Genetics Department, Kayseri, Turkey \\ ${ }^{5}$ Uskudar University, Medical Faculty, Pediatric Neurology Department Department, Umraniye, 34768 Istanbul, \\ Turkey
}

*Corresponding Author: Yesim Ozdemir; sevdayesimozdemir@gmail.com; sevdayesim.ozdemir@uskudar.edu.tr

Received 26 January 2022;

Accepted 23 February 2021;

Published 26 February 2022

\begin{abstract}
Smith-Kingsmore Syndrome is a very rare autosomal dominant intellectual disability syndrome characterized by macrocephaly, seizures, umbilical hernia, and facial dysmorphic features. The prevalence of SKS, with 27 patients reported so far, is still unknown. Rubinstein Taybi Syndrome Type 2 (RSTS2) is another rare genetic condition that prevalance is $<1 / 1.000 .000$. It is characterized by mental and developmental retardation, dysmorphic findings.

We present a seven-year-old girl who was diagnosed with SKS and RSTS2 based on identification of a novel de novo pathogenic variant in the MTOR and EP300 genes (MIM \#616638 and \#613684) by Whole Exome Sequencing and supported by some characteristic clinical features.

In our patient, pathogenic mutations belonging to two different ultra-rare syndromes were found. However, the patient had clinical findings of only Smith Kingmore Syndrome among the syndromes. Although he had a pathogenic mutation, she did not have the clinical findings of Rubinstein Taybi Syndrome. This the first case presenting two different mutation of these two ultra-rare syndromes.
\end{abstract}

Keywords: Smith-Kingsmore Syndrome, Rubinstein Taybi Syndrome Type2, MTOR, EP300, Exome Sequencing

\section{Introduction}

Smith-Kingsmore Syndrome (SKS) (MIM \#616638); is a rare autosomal dominant syndrome that is caused by a heterozygous germline mutation in MTOR gene (MIM \#601231) on chromosome 1p36. It was first described by Smith et al. in 2013 and characterized by overgrowth and intellectual disability [Smith et al., 2013]

It is also known as Macrocephaly-intellectual Disabilityneurodevelopmental Disorder-small Thorax Syndrome (MINDS; ORPHA 457485).

SKS is an ultra-rare syndrome characterized by macrocephaly, seizures, umbilical hernia, and facial dysmorphic features including frontal bossing, midface hypoplasia, small chin, hypertelorism with downslanting palpebral fissures, depressed nasal bridge, smooth philtrum, and thin upper lip [Moosa et al., 2017]
The prevalence of SKS, with 27 patients reported so far, is still unknown $(<1 / 1.000 .000$ in ORPHANET) [www.orpha.net]

The mTOR gene is a key regulator of cell growth, cell proliferation, protein synthesis and synaptic plasticity. The mTOR pathway is highly regulated and critical for cell survival and apoptosis [Gordo et al., 2018]. MTOR is functions via two protein complexes, mTORC1 and mTORC2, to control cell proliferation and growth [Yang et al., 2007]

Germline and somatic MTOR genetic alterations that activate mTOR signaling are found in many brain overgrowth disorders such as Focal Cortical Dysplasia (FCD), hemimegalencephaly, and diffuse megalencephaly [Mirzaa et al., 2016] intellectual disability, and seizures MTOR germline mutations in cohorts of patients with epilepsy with or without brain malformations [Moller et al., 2016]

Constitutive mTOR activation due to germline MTOR variants are associated with intellectual disability and macrocephaly [Baynam et al., 2015; Tsai et al., 2011] as well as 
polymicrogyria, seizures, and café-au-lait macules [Baynam et al.,2015]

Rubinstein Taybi Syndrome Type 2 (RSTS2) is another rare genetic condition (ORPHA 353284, MIM\# 613684) that prevalence is $<1 / 1.000 .000$. It is characterized by mental and developmental retardation, microcephaly, highly arched palate, down slanted palpebral fissures, abnormal smile, broad thumbs and halluces. RSTS2 is often caused by mutations in the CREBBP gene (\%50-70) and rarely from mutations in the EP300 gene (\%3) [www.orpha.net; Tsai et al., 2011]

\section{Materials and Methods}

\section{Case Report/Case Presentation}

The index patient presented to our neurology clinic at 7 age for hiperactivity and autistic behaviour and mental and intellectuel disability. She was also diagnosed with learning disability and autistic symptoms, and attention-deficit/hyperactivity disorder. Mother (33a) and father (35a) are nonconsagineous and have three
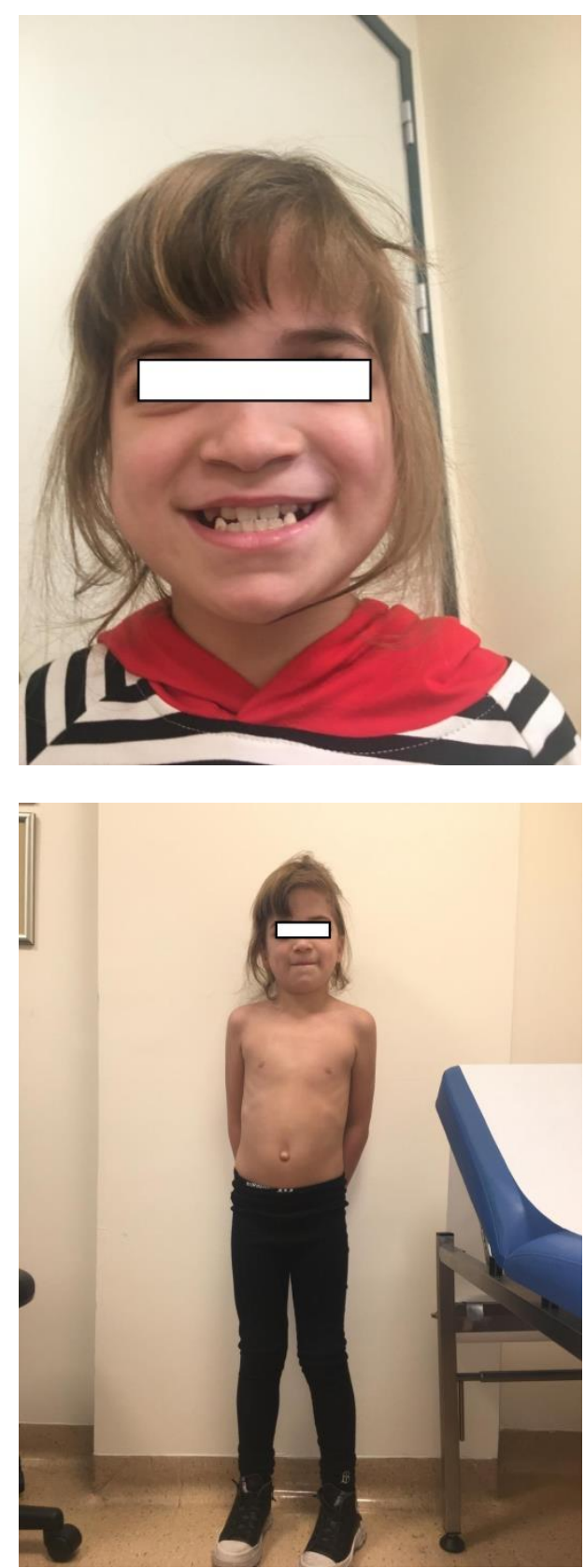

other healthy living children. In her history we found that she is the one of the 34 weeks dichorionic twins, $2800 \mathrm{~g}$ birth weight, didn't cry at the birth without cyanosis. She discharged after a day of intensive care unit hospitalisation. She had a non-febrile convulsion at first month with recurrences till the first year of her life. She erected her neck at the age of 14th month and walked at the 20th month. She was apathic, uninterested, and neurodevelopmental impaired child. She had bizzare hand movements, swimlike arm movements and got a visual and auditory hallucinations and autistic features. She began to talk at 5 th year old of her life and was receiving education in the special education group and needed speech therapy because of disarticulation and learning difficulties.

Physical examination; macrocephaly, tall forehead, frontal bossing, midface hypoplasia, hyper telorism, strabismus, downslanting palpebral fissures, short nose, depressed nasal bridge, smooth phyltrum, thin upper lip, high palate, macrostomia, caries, umblical hernia, short thumb and toes nails. She was consulted general surgeon for umblical hernia. (Figure 1a,b,c,d,e,f)
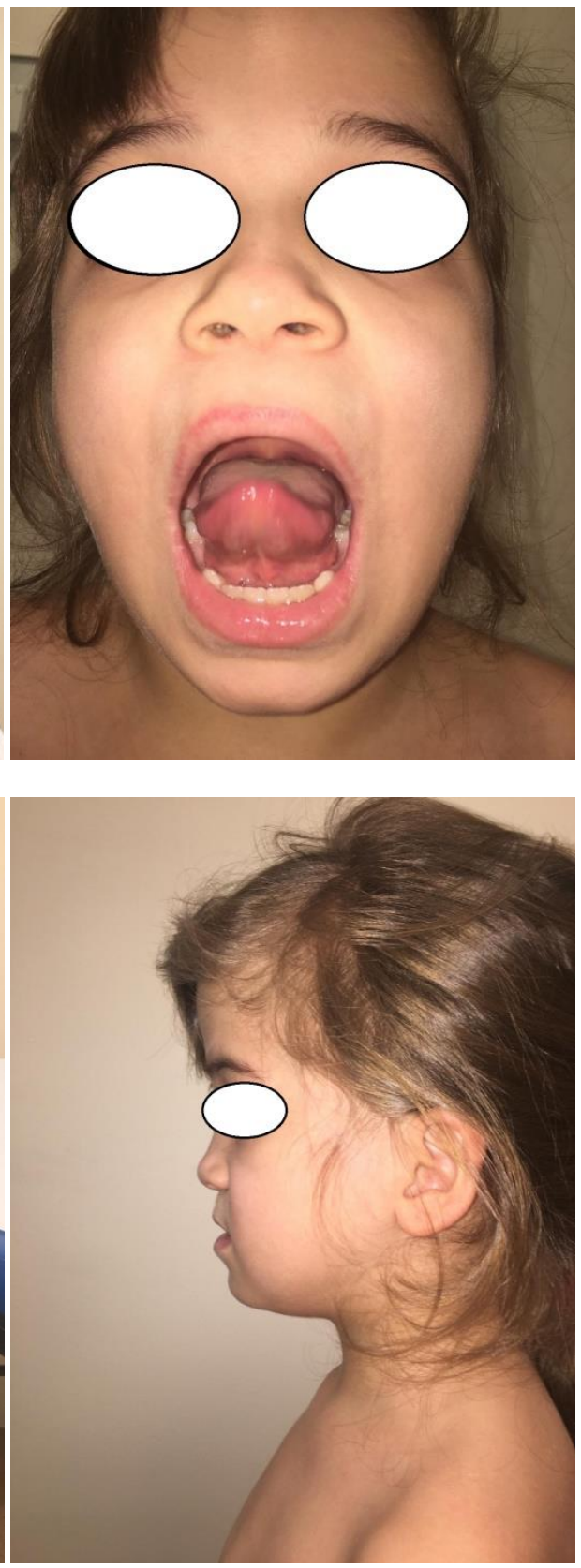

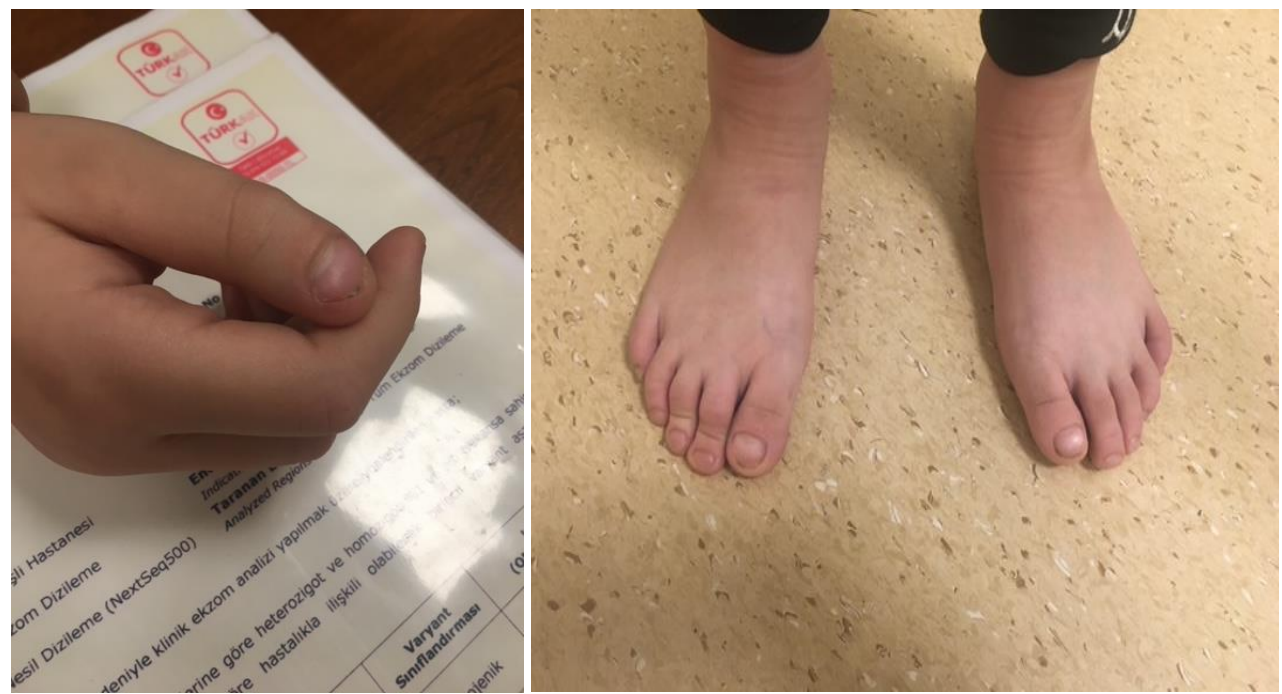

Fig. 1a, b, c, d, e, f: Shows the patient's phenotype. She has only SKS's clinical findings.

The patient has the clinical features of SKS. The clinical findings in our patient of RSTS and SKS are shown in Table 1 comparatively

Table 1: Our patient has the clinical features of both syndromes. The clinical findings in our patient of RSTS and SKS are shown in Table I comparatively

\begin{tabular}{|c|c|c|c|}
\hline SMITH KINGSMORE SYNDROME & & RUBINSTEIN-TAYBI SYNDROME 2; RSTS2 & \\
\hline $\begin{array}{l}\text { Caused by mutation in the mechanistic target of rapamycin gene } \\
\text { (MTOR, 601231.0001) }\end{array}$ & & $\begin{array}{l}\text { Caused by mutation in the } 300-\mathrm{KD} \text { E1A-binding } \\
\text { protein gene (EP300, } \underline{602700.0003})\end{array}$ & \\
\hline \multicolumn{4}{|l|}{ HEAD \& NECK } \\
\hline $\begin{array}{l}\text { - Macrocephaly } \\
\text { - Tall forehead } \\
\text { - Large anterior fontanel } \\
\text { - Frontal bossing } \\
\text { - Midface hypoplasia } \\
\text { - Small chin } \\
\end{array}$ & $\begin{array}{l}+ \\
+ \\
+ \\
+ \\
+ \\
+\end{array}$ & $\begin{array}{l}\text {-Microcephaly } \\
\text { - Micrognathia } \\
\text { - Retrognathia }\end{array}$ & $\begin{array}{l}- \\
+ \\
+\end{array}$ \\
\hline \multicolumn{4}{|l|}{ Eyes } \\
\hline $\begin{array}{l}\text { - Hypertelorism } \\
\text { - Downslanting palpebral fissures } \\
\text { - Strabismus }\end{array}$ & $\begin{array}{l}+ \\
+ \\
+\end{array}$ & $\begin{array}{l}\text { - Heavy, arched eyebrows } \\
\text { - Long eyelashes } \\
\text { - Downslanting palpebral fissures, mild }\end{array}$ & $\begin{array}{l}- \\
+ \\
+\end{array}$ \\
\hline \multicolumn{4}{|l|}{ Nose } \\
\hline $\begin{array}{l}\text {-Short nose } \\
\text { - Depressed nasal bridge }\end{array}$ & $\begin{array}{l}- \\
+\end{array}$ & $\begin{array}{l}\text { - Prominent nose } \\
\text { - Beaked nose } \\
\text { - Long columella extending below the alae nasi }\end{array}$ & $\begin{array}{l}- \\
- \\
-\end{array}$ \\
\hline \multicolumn{4}{|c|}{ C } \\
\hline $\begin{array}{l}\text { - Macrostomia } \\
\text { - Open mouth posture } \\
\text { - Long philtrum } \\
\text { - Smooth philtrum } \\
\text { - Thin upper lip }\end{array}$ & $\begin{array}{l}+ \\
+ \\
+ \\
+ \\
-\end{array}$ & $\begin{array}{l}\text { - Narrow palate } \\
\text { - High-arched palate } \\
\text {-Dental malocclusion } \\
\text { - Overbite } \\
\text { - Dental caries- } \\
\text {-Grimacing smile }\end{array}$ & $\begin{array}{l}- \\
+ \\
+ \\
+ \\
- \\
+\end{array}$ \\
\hline \multicolumn{4}{|l|}{ ABDOMEN-CHEST } \\
\hline $\begin{array}{l}\text { Diastasis recti } \\
\text { Umbilical hernia- } \\
\text { Small thorax }\end{array}$ & $\begin{array}{l}- \\
+ \\
+\end{array}$ & $\begin{array}{l}\text { - Malrotation (in some patients) } \\
\text { - Feeding/swallowing issues beyond the neonatal } \\
\text { period (in some patients) }\end{array}$ & $\begin{array}{l}- \\
+\end{array}$ \\
\hline \multicolumn{4}{|l|}{ SKELETAL } \\
\hline \multicolumn{4}{|l|}{ Hands } \\
\hline $\begin{array}{l}\text {-Deep palmar creases } \\
\text { - Short proximal phalanges } \\
\text { - Short distal phalange } \\
\end{array}$ & $\begin{array}{l}- \\
- \\
+\end{array}$ & $\begin{array}{l}\text { - Broad thumbs } \\
\text { - Square distal fingertips- } \\
\text { - Broad great toes } \\
\end{array}$ & $\begin{array}{l}? \\
- \\
+\end{array}$ \\
\hline \multicolumn{4}{|l|}{ NEUROLOGIC } \\
\hline $\begin{array}{l}\text { - Intellectual disability } \\
\text { - Seizures (in some patients) } \\
\text { - Mild prominence of the ventricular system } \\
\text { - Hypogenesis of the body and the splenium of the corpus callosum } \\
\text { - Generalized white matter loss } \\
\text { - Small mesencephalon, pons and medulla } \\
\text { - Perisylvian polymicrogyria } \\
\text { - Heterotopic gray matter in the right frontal lobe }\end{array}$ & $\begin{array}{l}+ \\
+ \\
+\end{array}$ & $\begin{array}{l}\text { - Mental retardation, mild to moderate } \\
\text { - Autism spectrum disorder (in some patients) } \\
\text { - Delayed psychomotor development } \\
\text { - Delayed gross motor development } \\
\text { - Speech delay } \\
\text { - Hypotonia }\end{array}$ & $\begin{array}{l}+ \\
+ \\
+ \\
+ \\
+ \\
+ \\
+\end{array}$ \\
\hline \multicolumn{4}{|l|}{ Behavioral Psychiatric Manifestations } \\
\hline -Autistic features & + & $\begin{array}{l}\text { - Hyperactivity } \\
\text { - Behavioral difficulties }\end{array}$ & $\begin{array}{l}+ \\
+ \\
+\end{array}$ \\
\hline
\end{tabular}




\section{Material and Method}

After obtaining written informed consent, blood samples were taken from the patient for genetic study. Genomic DNA was isolated from peripheral blood leukocytes using a QIAamp DNA Blood Mini kit ${ }^{\circledR}$ (Qiagen GmbH, Hilden, Germany) and Clinical Exomes sequencing was performed using Illumina NextSq500 system (Illumina, Inc.). To obtain a clear clinical diagnosis quickly, the patient was screened for causal variants using WES. The candidate variants were first screened with the criterion of a minor allele frequency $<1 \%$ against the 1,000 Genomes Project, the NHLBI exome variant server or in 50 HapMap control exomes. The area of analysis included each exon and $\sim 20$ bp of exon-intron boundaries.

Discussion/Conclusion

Results

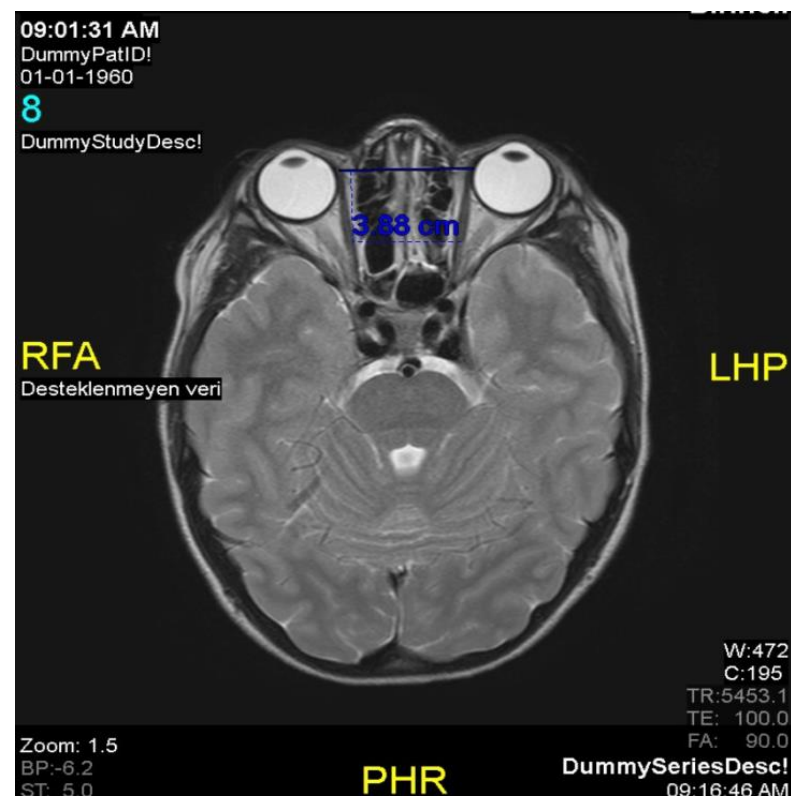

It was identified de novo mutations in MTOR gene (c.5663T $>$ G (p.Phe1888Cys) and EP300 gene (c.6627_6638delCCAGTTCCAGCA

(p.Asn2209_Gln2213delinsLys) heterozygot deletion-insertion by performed WES. Both variants were described to be diseasecausing and patogenic by ClinVar [Handoko et al., 2018]. Sanger confirmation and segregation analysis revealed that all variants occurred de novo, suggesting that they are pathogenic. All other biochemical, immunological and metabolic findings were normal.

\section{Radiology and EEG}

EEG was normal. Cranial MRI showed macrocephaly, hyper telorism, cerebral polymicrogyry, mild dilatation of the perivascular system and generalized mild white matter loss. The cerebellum was normal (Figure 2a,b,c)

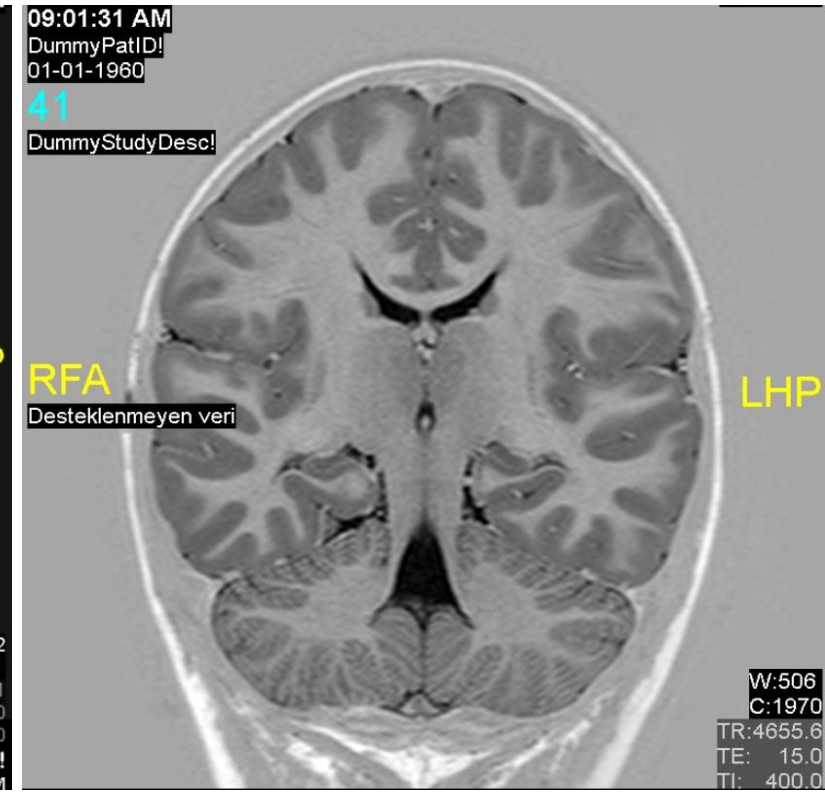

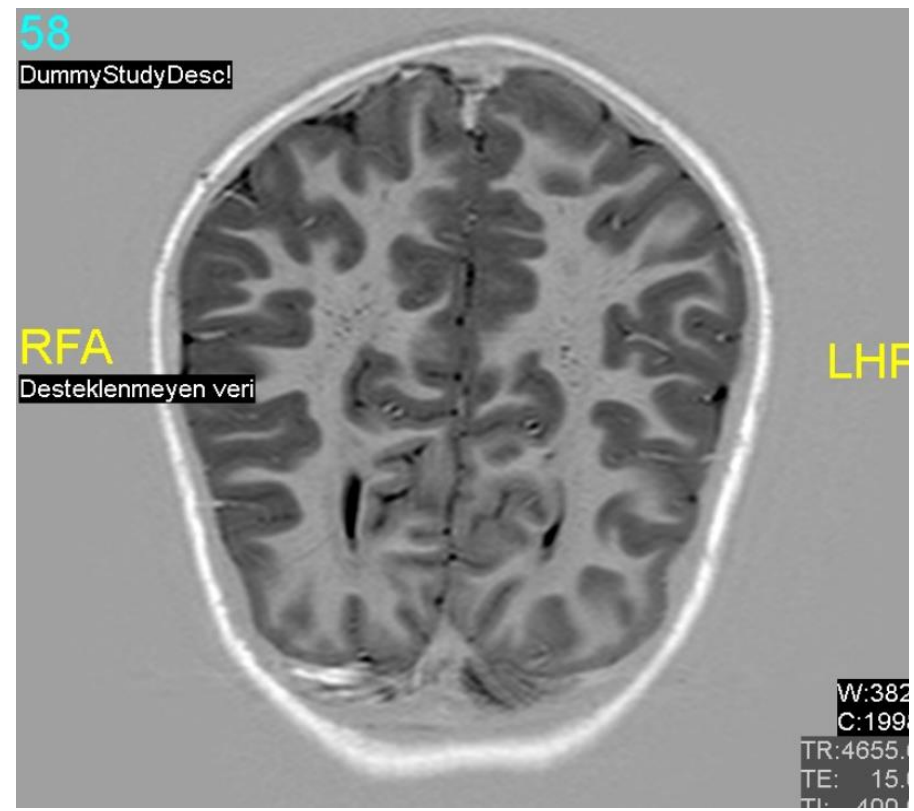

Fig. 2a, b, c: Shows the patient's MRI. She has macrocephaly, hypertelorism, polymicrogyria

\section{Results and Discussion}

The first case presenting two pathogenic variants in two ultra-rare syndromes (SKS and RTS-2) and has only one's clinical findings.
This study confirms the important role of somatic MTOR mutations in the pathogenesis of FCD, and jointly with previous reports shows that germline MTOR mutations may contribute to a broad phenotypic spectrum, ranging from focal epilepsy without 
MRI-detectable brain abnormalities and normal development, to hemimegalencephaly, intellectual disability, and epilepsy [Handoko et al., 2018]

The treatment effectiveness in these patients with mTORC1 pathway inhibitors needs further evaluation, but meanwhile, screening of MTOR in a broad range of focal epilepsies is warranted.

In this article we observed that our case has the same point with identical twins patients published before (10a-b) This twins has the mutation c.5663A $>C / p$. Phe1888Cys instead of our patient has c.5663T $>\mathrm{G}$

In this article Moller et al. described patients with the same mutation. But our case presented patogenic variant of RTST2 (EP300 gene) besides the MTOR mutation. Our patient has the two patogenic variants in two different gene but only SKS's clinical findings. In Table 2 shown that comparison of the characteristics of our patient with other published cases of the mosaic MTOR p.Thr1977Ile variant.

Table 2: Comparison of the characteristics of our patient with other published cases of the mosaic MTOR p.Thr1977Ile variant

\begin{tabular}{|c|c|c|c|}
\hline Characteristics & $\begin{array}{l}\text { Our Patient } \\
\text { (MTOR- EP300 mutation) }\end{array}$ & $\begin{array}{l}\text { Handoko et al.,2018 Patient 10a } \\
\text { MTOR }\end{array}$ & $\begin{array}{l}\text { Handoko et al., } 2018 \text { Patient 10b } \\
\text { MTOR }\end{array}$ \\
\hline Sex/age & & $F / 23$ & $F / 23$ \\
\hline Variant Cdna protein & $\begin{array}{l}\text { c.5663T }>\mathrm{G} \\
\text { (p.Phe1888Cys)-MTOR } \\
\text { c.6627_6638delCCAGTTCCAGCA } \\
\text { (p.Asn2209_Gln2213delinsLys) EP300 }\end{array}$ & $\begin{array}{l}\text { c.5663A }>C \\
\text { p.Phe1888Cys-MTOR }\end{array}$ & $\begin{array}{l}\text { c.5663A }>C \\
\text { p.Phe1888Cys-MTOR }\end{array}$ \\
\hline Inheritance & Germline de novo & Germline de novo & Germline de novo \\
\hline $\begin{array}{l}\text { Family history of } \\
\text { seizures }\end{array}$ & No & $\begin{array}{l}\text { Identical twin } \\
\text { sister same } \\
\text { phenotype }\end{array}$ & $\begin{array}{l}\text { Identical twin } \\
\text { sister same } \\
\text { phenotype }\end{array}$ \\
\hline Age at seizures onset & 2 month & $4 y$ & $6 y$ \\
\hline Seizures description & $\begin{array}{l}\text { Generalized tonic-clonic or } \\
\text { Giddy laughing with hyperactivity }\end{array}$ & $\begin{array}{l}\text { Irresponsive } \\
\text { preceded or } \\
\text { followed by } \\
\text { detached } \\
\text { laughing; TCS; } \\
\text { convulsive status } \\
\text { epilepticus }\end{array}$ & $\begin{array}{l}\text { Giddy laughing } \\
\text { with } \\
\text { hyperactivity; } \\
\text { TCS; convulsive } \\
\text { status epilepticus } \\
\text { (age 8) }\end{array}$ \\
\hline EEG & Normal & $\begin{array}{l}\text { Persistent diffuse } \\
\text { sharp and slow } \\
\text { wave activity, } \\
\text { most prominent } \\
\text { over right } \\
\text { hemisphere }\end{array}$ & $\begin{array}{l}\text { Mild slow } \\
\text { background, } \\
\text { diffuse and left } \\
\text { centro-temporal } \\
\text { epileptiform } \\
\text { discharges }\end{array}$ \\
\hline Epilepsy syndrome & Generalized tonic-clonic & $\begin{array}{l}\text { Focal epilepsy, } \\
\text { probably frontal } \\
\text { or temporal lobe }\end{array}$ & $\begin{array}{l}\text { Focal epilepsy, } \\
\text { probably frontal } \\
\text { or temporal lobe }\end{array}$ \\
\hline MRI Findings & $\begin{array}{l}\text { Polymicrogyry, mild prominence of the } \\
\text { ventricular system, hypertelorism, } \\
\text { generalized white matter loss. }\end{array}$ & $\begin{array}{l}\text { Ventricular prominence with mild } \\
\text { extra ventricular } \\
\text { enlargement } \\
\text { at } 6 \mathrm{mo}(1.5 \mathrm{~T})\end{array}$ & $\begin{array}{l}\text { Mild ventricular } \\
\text { prominence at } \\
6 \mathrm{mo}(1.5 \mathrm{~T})\end{array}$ \\
\hline $\begin{array}{l}\text { Cognition before } \\
\text { onset sz }\end{array}$ & Delayed & Delayed & delayed \\
\hline $\begin{array}{l}\text { Cognition and } \\
\text { behavior after } \\
\text { sz onset }\end{array}$ & $\begin{array}{l}\text { Moderate ID, } \\
\text { Autism, hallucination, } \\
\text { self mutilation }\end{array}$ & $\begin{array}{l}\text { Moderate ID, } \\
\text { aerophagia, } \\
\text { autism }\end{array}$ & $\begin{array}{l}\text { Moderate ID, } \\
\text { autism }\end{array}$ \\
\hline $\begin{array}{l}\text { Neurologic } \\
\text { Examination }\end{array}$ & & $\begin{array}{l}\text { Hypotonia, } \\
\text { nonverbal, } \\
\text { shuffling gait }\end{array}$ & $\begin{array}{l}\text { Hypotonia, } \\
\text { nonverbal, } \\
\text { shuffling gait }\end{array}$ \\
\hline $\begin{array}{l}\text { Dysmorphic } \\
\text { features, } \\
\text { including head } \\
\text { circumferences }\end{array}$ & $\begin{array}{l}\text { Macrosefali, tall forehead, frontal } \\
\text { bossing, midface hypoplasia, hyper } \\
\text { telorism, strabismus, downslanting } \\
\text { palpebral fissures, short nose, depresse } \\
\text { nasal bridge, smooth phyltrum, thin } \\
\text { upper lip, high palate, macrostomia, } \\
\text { long thin extremities, umblical hernia, } \\
\text { broad-great toes, short thumb and toes } \\
\text { nails. }\end{array}$ & $\begin{array}{l}\text { Macrocephaly:HC: } 61.3 \mathrm{~cm} \text { at } 12 \\
\text { y } \\
\text { (15.8 SD). Facial } \\
\text { dysmorphy: } \\
\text { prominent forehead, low-set ears, } \\
\text { gingival hyperplasia, frontal } \\
\text { bossing, kyphosis, micrognathia, } \\
\text { long thin extremities }\end{array}$ & \\
\hline
\end{tabular}


Gordo et al. has published first 23 patients with SKS, Handoko et al added 24th case, Garcia et al.,(2019) added 25th case with an ant phospholipid syndrome on the same patient. Plaza's case (2020) was the 26th SKS case. Our case will be the 27th case. But the importance of this case who presents a pathogenic variant and clinical findings of another rare syndrome, RTST2. Than it is the first case presenting two different mutations of these two rare syndromes. This case recall us two rare syndrome could be overlapped on a poor child.

\section{Ethics approval and consent to participate}

The paper is exempt from ethical committee approval, because it is not clinical research paper. Written informed consent was obtained from the patient for publication of this case report and any accompanying images. If your manuscript does not report on or involve the use of any animal or human data or tissue, please state "Not applicable" in this section.

\section{Data Availability}

All data generated or analyzed during this study are included in this article [and/or] its supplementary material files. Further enquiries can be directed to the corresponding author.

\section{Conflicts of Interest}

The authors have no conflicts of interest to declare.

\section{Funding Statement}

None

\section{Authors' contributions}

Yesim Ozdemir, conception of the work, drafting the work, final approval of the publication, the acquisition and analysis of genetic results of WES, agreed the accountability for all aspects

Murat CAG, drafting the work for surgical aspect of the content, final approval of the publication

Munis Dundar, design of the work, the acquisition and analysis of genetic results of WES, final approval of the publication

Aslihan Kiraz, design of the work, the acquisition and analysis of genetic results of WES, final approval of the publication

Cihan Meral, interpretation of data for the work, drafting the work for neurological aspect of the content

\section{References}

[1] Baynam G, Overkov A, Davis M: A germline MTOR mutation in aboriginal Australian siblings with intellectual disability, dysmorphism, macrocephaly, and small thoraces. Am. J. Med. Genet 167: 1659-1667 (2015).

[2] Gordo G, Tenorio J, Arias P, Santos-Simarro F, GarcíaMiñaur S: mTOR mutations in Smith-Kingsmore syndrome: four additional patients and a review. Clin Genet 93: $762-775$ (2018).

[3] Handoko M, Emrick LT, Rosenfeld JA, Wang X, Tran AA et al: Recurrent mosaic MTOR c.5930C > T
(p.Thr1977Ile) variant causing megalencephaly, asymmetric polymicrogyria, and cutaneous pigmentary mosaicism: Case report and review of the literature. Am J Med Genet 179: 475-479 (2018)

[4] https://www.ncbi.nlm.nih.gov/clinvar/?term=mtor\%5Bge ne\%5D (Acces date: December 2021)

[5] https://www.orpha.net (Access date: December2021)

[6] Mirzaa GM, Campbell CD, Solovieff N, Goold C, Jansen LA et al: Association of MTOR mutations with developmental brain disorders, including megalencephaly, focal cortical dysplasia, and pigmentary mosaicism. JAMA Neurol 73: 836-845 (2016)

[7] Moller RS, Weckhuysen S, Chipaux M, Marsan E, Taly $\mathrm{V}$ et al: Germline and somatic mutations in the MTOR gene in focal cortical dysplasia and epilepsy. Neurol. Genet 2: e118 (2016)

[8] Moosa S, Bohrer-Rabel H, Altmuller J, Beleggia F, Nürnberg $\mathrm{P}$ et al: Smith-Kingsmore syndrome: A third family with the MTOR mutation c.5395G>A p.(Glu1799Lys) and evidence for paternal gonadal mosaicism. Am J Med Genet A 173: 264-267 (2017)

[9] Mroske C, Rasmussen K, Shinde DN, Huether R, Powis Z, Hsiao-Mei Lu et al. Germline activating MTOR mutation arising through gonadal mosaicism in two brothers with megalencephaly and neurodevelopmental abnormalities. BMC Med Genet 16: 102 (2015)

[10] Plazas A, Ibarra-Ram'irez M, Garza-B’aez A, Elia Mart'inez-de-Villarreal L: Expanding the phenotype of MTOR-related disorders and the Smith-Kingsmore syndrome. Neurol Genet 6:e432. (2020)

[11] Rodríguez-García ME, Cotrina-Vinagre FJ, Bellusci M, de Aragón AM, Hernández-Sánchez L et al: A novel de novo MTOR gain-of-function variant in a patient with Smith-Kingsmore syndrome and Antiphospholipid syndrome. Eur J Hum Genet doi: 10.1038/s41431-0190418-1.

[12] Smith LD, Saunders CJ, Dinwiddie DL, Andrea M. Atherton, et al: Exome sequencing reveals de novo germline mutation of mammalian target of rapamycin (MTOR) in a patient with megalencephaly and intractable seizures. J. Genomes Exomes 2: 63-72 (2013)

[13] Tsai ACH, Dossett CJ, WaltonCS, Nishi E, Kitazawa N et al: Exon deletions of the EP300 and CREBBP genes in two children with Rubinstein-Taybi syndrome detected by aCGH. Europ. J. Hum. Genet 19: 43-49 (2011)

[14] Yang Q, Guan KL. Expanding mTOR signaling. Cell Research 17(8): 666-681 (2007) 
indicated otherwise in a credit line to the material. If material is not included in the article's Creative Commons license and your intended use is not permitted by statutory regulation or exceeds the permitted use, you will need to obtain permission directly from the copyright holder. To view a copy of this license, visit https://creativecommons.org/licenses/by/4.0/.

(c) The Author(s) 2021 